\title{
COMPARECENCIA DE CARLOS GARAIKOETXEA URRIZA EN LA COMISIÓN ESPECIAL SOBRE AUTOGOBIERNO DEL PARLAMENTO VASCO (27.2.2002)
}

\author{
HEARING OF CARLOS GARAIKOETXEA URRIZA IN THE SPECIAL COMMITTEE \\ ON SELF-GOVERNMENT OF THE BASQUE PARLIAMENT (2002.2.27)
}

\section{Carlos Garaikoetxea Urriza}

Lehendakari del Gobierno Vasco (1980-1985)

Cómo citar / Nola aipatu: Garikoetxea Urriza, C. (2020). Comparecencia de Carlos Garaikoetxea Urriza en la Comisión Especial sobre Autogobierno del Parlamento Vasco (27.2.2002). Legebiltzarreko Aldizkaria - LEGAL - Revista del Parlamento Vasco, (1): $226-255$. https://doi.org/10.47984/legal.2020.010

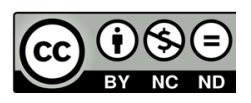

\section{NOTA SOBRE LA COMPARECENCIA}

Al repasar la comparecencia parlamentaria con la que traté de explicar el proceso de restauración de nuestro autogobierno, me parece oportuno subrayar las circunstancias y motivaciones que nos aconsejaron elegir el camino más conveniente para nuestro País siguiendo la senda estatutaria.

Huelga subrayar que en las aspiraciones de quienes protagonizamos aquel proceso existían, tanto y más que hoy, metas que estaban plagadas de dificultades insalvables: nuestra aspiración de poder ejercer el derecho de autodeterminación del Pueblo Vasco en las circunstancias propias de una transición desde el franquismo, que mantenía vivos aparatos del Estado herederos de la dictadura, encarnaba dificultades que, en el mejor de los casos, se estrellarían contra la oposición insalvable de esos aparatos y sus instituciones. Y en el peor, desembocarían en un retorno trágico al pasado. En lugar de una postura testimonial estéril, si no trágica, teníamos presentes las graves urgencias del País, que requerían un poder político que, aunque con sus limitaciones, nos permitiera afrontar: 
El control de los recursos hacendísticos capaces de aliviar y reimpulsar la crisis económica y social del País. Sirva de recordatorio que zonas de Bizkaia sufrían un paro superior al 30\% de su población activa. Acabar con el expolio fiscal y recuperar una hacienda propia constituía un objetivo prioritario, aunque para algunos el Concierto Económico no pareciera el capítulo reivindicativo de mayor impacto político emocional. Sin embargo, sus consecuencias fueron trascendentales para apuntalar industrias en crisis y diseñar políticas renovadoras basadas en $\mathrm{I}+\mathrm{D}$.

Apuntalar la recuperación del euskara, en la enseñanza o los medios de comunicación, la cultura, la enseñanza en todos sus niveles, la investigación, mejorar la sanidad, la sustitución de las fuerzas de seguridad del Estado, salvo en aspectos "supracomunitarios" (aunque su interpretación luego resultara abusiva por parte del Estado).

En suma, quisimos avanzar en bases de la construcción del autogobierno, bases que también habría que transitar desde la más radical de las reivindicaciones, y que resultaban imprescindibles y útiles para un periodo de tiempo relevante.

Por cierto, cuando hoy se discute (especialmente en Catalunya), la vía "unilateral" o pactada hacia la independencia, no me resisto a recordar la "vía foral", de alcances teóricos ilimitados, que elegimos algunos como régimen excepcional para los vascos en el proceso constitucional. Me permito recordar, con pesar, que personalmente discutí denodadamente (aquí y en Madrid) para que la vía "pactada" excepcional entre los representantes del Estado y los vascos para la restauración del autogobierno, de alcance indefinido, prevaleciera en vez de la fórmula limitativa "en el marco de la Constitución y el Estatuto", que finalmente figuró como "dique" constitucional. La vía del pacto, que discutí con propios y extraños, es hoy actualidad cuando se habla de "unilateralidad" en el avance del autogobierno que choca con el muro de la Constitución y los gobiernos del Estado, frente al alcance sin límites previsibles de una excepcional vía foral pactada, excepción de la Constitución para el caso vasco. ¿Qué poderes no podrían reivindicarse con una invocación retrospectiva de nuestra historia, sin el techo constitucional presente? 


\section{COMPARECENCIA DE D. CARLOS GARAIKOETXEA URRIZA, A PETICIÓN DE LA COMISIÓN, A FIN DE QUE APORTE DATOS E INFORMACIONES ACERCA DE LAS MATERIAS OBJETO DE ESTUDIO DE LA COMISIÓN ESPECIAL SOBRE AUTOGOBIERNO.}

PARLAMENTO VASCO, 27.2.2002

\section{CARLOS GARAIKOETXEA URRIZA JAUNAREN AGERRALDIA, BATZORDEAK ESKATUTA, DATUAK ETA INFORMAZIOAK EMAN DITZAN AUTOGOBERNUARI BURUZKO BATZORDE BEREZIAK DITUEN AZTERGAIEI BURUZ.} EUSKO LEGEBILTZARRA, 2002.2.27

Transcripción literal de la comparecencia / Agerraldiaren hitzez hitzeko transkripzioa La PRESIDENTA (Sra. Piñol Olaeta):

... Bigarren puntua, gai-zerrendako bigarren puntua: "Carlos Garaikoetxea Urriza jaunaren agerraldia, batzordeak eskatuta, datuak eta informazioak eman ditzan Autogobernuari buruzko Lantalde Bereziak dituen aztergaiei buruz". Labur-labur azalduko dot zer prozedura jarraituko dogun geratzen jakuzan gai-zerrendako puntu guztietan: alde batetik, presidentziaren aldetik esposizio txiki bat, laburra, egingo dot, batez be kokatzeko gonbidatuak zer zerikusi daukan Estatutuaren prozesu guzti horrekin, zuzenean berari emango deutsogu berba, eta bere esposizioaren ostean -nik uste, ordu erdi edo hiru ordu laurdeneko esposizioa, gutxi gora-behera, izan ondoren-, alderdi guztien txanda zabalduko geunke. Nik eskatuko deutsuet, mesedez..., asmoa da txanda bakarra zabaltzea, batez be gai-zerrenda honetan lau agerraldi ditugulako eta orduak -ahal dogun neurrian, behintzat- errespetatu behar doguzalako.

Eta, beraz, ja aurrera jarraituz, eta Garaikoetxea Urriza jaunaren inguruan, ba, nik uste dot danok ezagutzen dozuela eta presentazioak ia-ia soberan dagozala, baina dana dala esan behar bera izan zala Consejo General Vasco-ko presidentea eta baita, Gernikako Estatutoa onartu zanean, lehenengo lehendakaria. Horregatik, nik uste dot hori esanda eta hola kokatuta argi eta garbi geratzen dala bera hona ekartzea oso balio handikoa dala batez be batzordearen lanak aurrera eroateko.

Eta beste barik, eta eskertuz behintzat batzorde honen izenean benetan jaso dozun gonbidapena onartzea eta hona etortzea, hori esanda, beste barik, Garaikoetxea jaunari emango deutsot berba. Zeuk daukazu berba. 
Eskerrik asko, presidente andrea.

Egun on, legebiltzarkideok, jaun-andreok.

Zuen arreta eskertzen dizuet Autogobernuari buruzko Batzorde honetan nire iritzia eskatzeagatik. Izan ere, ni, oker ez banago, lehenengoa naiz, eta nere azalpena eta nere prozedura egokiak izango direla espero dut.

Gai honi buruzko beste iritzi guztiak errespetatuz, nik hitz gutxitan laburtuko nuke neure ikuspuntua: gaur begiztatzen dugun Estatutua ez da 1979 urtean sinatutakoa; orduan lortutako paktua ez da bete, orduan lortutako betebehar edo konpromezu zail eta orekatua alde bakar batek hautsi egin du, gaur egun ezagungaitz bihurtuz Gernikako Estatutua. Larriena, bere jatorrizko zentzua bereganatzea gero eta zailagoa dela da.

1981 urtetik geroztik atzerapauso bat izan bazen, LOAPA delakoa izanik bere adierazpenik argiena eta ordezkatu zuten lege-neurriak, gaur oraindik larriagoa den erasoaldi baten aurrean gaude, Gobernu zentralak aurkeztutako neurri eta politikarekin. Guzti honengatik, Estatutuak berezko ezaugarri nabarienetarikoak galtzen ditu, betebehar edo, esan dudan bezala, konpromezu orekatu baten balorea, izaera paktatua paktatua moral eta formalki-, bere espezifikotasun edo bereiztasuna beste estatutoengandik bereizten duena. Eta horregatik -eta horrela bukatzen dut nere laburpena-, autogobernurako garrantzia eta aldi historiko aipagarriago batetarako bere balioak ere galtzen ditu.

Yo he dicho, con palabras que por su brevedad pretendían ser contundentes y nada equívocas, que, a mi entender, el Estatuto que hoy contemplamos no es el Estatuto que negociamos en el año 79 , he dicho que con todo el respeto a otras opiniones que pueda haber de signo contrario. He dicho que, para mí, se ha incumplido un pacto, un pacto basado en un compromiso político contraído en circunstancias muy especiales -a ello me referiré-, y que, por añadidura, a mayor abundamiento, no se han respetado especificidades evidentes de ese Estatuto.

Me refiero en primer lugar al carácter de compromiso político que en aquel momento histórico supuso el Estatuto. A nadie se ocultan las circunstancias, circunstancias que exigieron grandes dosis de pragmatismo y hasta de renunciaciones políticas, en aras de consolidar un proceso democrático naciente, no sólo aquí, sino en todo el Estado, y, en ese sentido, la palabra "equilibrio" adquiere para mí toda su relevancia y todo el respeto que merece, insisto, por las especialísimas circunstancias (no hace falta que sea más explícito) en que hubo de negociarse, eso y otras cosas.

Por otro lado, frente a fáciles críticas que puede suscitar esta alusión, las urgencias del país eran realmente apremiantes, apremiantes en todos los órdenes. Desde el punto de vista económico, el país se estaba desangrando, por citar un dato elocuente, con una caída del producto interior bruto, en tres años, creo que del 12 por ciento. Los déficit infraestructurales eran bestiales: todo el mundo puede recordar aquellos monumentos 
a la inoperancia en infraestructuras, que eran un puente de Rontegi detenido y los déficit infraestructurales..., qué sé yo, cálculos que hacían las Cámaras de Comercio, como la vizcaína, en cientos de miles de millones de pesetas de los de la época. El expolio fiscal era terrorífico...

No creo que con esto estoy haciendo una descripción apocalíptica en la que no crea ninguno de los presentes que conozca los datos de la época, pero en el orden cultural, lingüístico, etcétera, y otros muchos puntos igualmente sensibles para quien les habla, y creo que para una gran mayoría de este país, la condición de situación de emergencia a la que me refiero era indudable.

Y en circunstancias semejantes el pragmatismo y la necesidad de llegar a acuerdos realistas, responsables, y no hacer política-ficción, era absolutamente necesario. Y en ese sentido, repito, el acuerdo político, al que además me referiré más adelante, para poder calificarlo como tal, el compromiso al que se llegó, fue una necesidad. Y una necesidad en circunstancias, como digo, muy especiales, en las que el sentido de la responsabilidad para salvar lo que había que salvar a la salida de una dictadura tuvo que ser, en cualquier fuerza política responsable, especialmente importante.

Corolario de todo esto, el respeto que merece un compromiso contraído en estas circunstancias también es especialmente importante.

Hubo un pacto. Se ha abusado mucho, en las definiciones históricas de determinados estatus político-institucionales existentes en el país, al hablar de la palabra "pacto", etcétera, sea desde las leyes que dimanan del primer expolio foral, la ley paccionada de 1841 en Navarra, etcétera, etcétera, que han merecido el calificativo de "pacto", y no desde el nacionalismo solamente. Pero yo digo que en este caso hubo elementos constitutivos de un pacto tan importantes y más que en cualquiera de esas circunstancias a las que con tanta frecuencia, sobre todo cuando interesa, se alude a su naturaleza pactada.

Y desde un punto de vista formal y desde un punto de vista moral, he dicho antes. Desde un punto de vista formal bastaría, qué sé yo, citar la propia Constitución en su artículo 152.2, cuando dice que el procedimiento para su aprobación se realizará a través, primero, de una comisión constitucional del Parlamento español, y de una delegación de asambleas de parlamentarios vascos, que si llegan a un común acuerdo -se dice- tendrá el refrendo de un referéndum en el país y de una ley especial en el Parlamento español.

Podríamos adentrarnos, pero creo que no es mi misión -pero sí me parece importante recordar todo esto para después entrar en otros detalles-, en el sustrato foral que alienta en todo el Estatuto, de una manera intencionada y además elegida para darle ese carácter, desde el punto de vista cualitativo, especial de su anclaje en un marco institucional, cuya característica tantas veces invocada es la característica del pacto. Y en las alusiones, constantes además, para conferir al Estatuto una especificidad o una asimetría, como se emplea ahora con frecuencia al hablar de estas cosas, respecto a otras 
situaciones autonómicas, las alusiones que son constantes para abrir una vía también específica al ámbito competencial del Estatuto vasco.

De manera que ese anclaje en la foralidad histórica, por otra parte la manera más realista, la única quizá, de recabar una profundidad en el autogobierno y una calidad en su base, la única realista en la época, es constante.

Pero, aparte de esto, yo me siento especialmente obligado a referirme a lo que he calificado de "carácter moral pactado" del Estatuto.

Yo en aquella época, como ha recordado la señora Presidenta, era Presidente del Consejo General Vasco, o Gobierno provisional, si así se le quiere llamar, y también presidente de la ejecutiva del Partido Nacionalista Vasco (dicho de paso, partido que contaba bastante en la época, como ahora), y cuando ya se había puesto en marcha la preparación del borrador y de la propuesta de Estatuto - tengo aquí apuntado-, el 22 de junio del 79, el Presidente Suárez me pidió una reunión, muy larga reunión (si mal no recuerdo, duró como cinco horas), en la que me preguntó qué procedimiento consideraba que podía ser el más interesante para impulsar el Estatuto y llegar a un acuerdo.

Entendía él que el Parlamento era, naturalmente, una instancia establecida legalmente y por la que tendría que ir todo el proceso, pero no se le ocultaban, y tenía razón, las dificultades que tendría un acuerdo en el Parlamento, dada la variedad de posturas allí existentes, desde Blas Piñar o el señor Fraga Iribarne, que votaron en contra, a la de un señor Aizpún, que decía ya en el debate constitucional que él se oponía a todo lo que permitiera acercarse a un estado separatista de Euskadi, textualmente. Y, en ese sentido, se presentaba la negociación en el Parlamento español, como es lógico, pues, muy complicada.

Entonces, yo personalmente le propuse que se produjera una negociación que tuviera carácter de tal, y que se formalizara con el acuerdo y las firmas correspondientes, mediante una comisión técnico-política del máximo nivel, integrada en gran parte por miembros del propio Gobierno central y una representación que estaba integrada fundamentalmente por representantes nacionalistas del más alto nivel también (podríamos entrar en detalles, pero, vamos, yo creo que si a alguien le interesan nombres, etcétera, luego podremos ser más explícitos), y algún independiente.

Y asumimos que, a la vez, hubiera otra instancia negociadora, en la que estaríamos él como Presidente del Gobierno y yo como Presidente del Consejo General Vasco, para ir desatascando los problemas que se revelaran más difíciles, en los que hubiera algún colapso en dicha negociación. Y ese fue el procedimiento que se siguió.

Al mismo tiempo, asumimos el compromiso, asumí yo el compromiso de evacuar las consultas con los que no estuvieran presentes en aquella comisión técnica y que habían intervenido en la redacción del Estatuto. Había habido 18 propuestas en una ponencia designada por la Asamblea de Parlamentarios Vascos a instancias del Consejo General Vasco, y de allí había salido un texto razonablemente consensuado, con algunas objeciones del Partido Socialista, pero en términos generales aceptándolo, y 
con más motivos de desacuerdos -que así se llamaron- de la UCD de entonces, cuyo máximo responsable, Chus Viana, a quien quiero dedicar el recuerdo más entrañable, porque fue un gran amigo y un gran parlamentario, no obstante, vertía -y es importante decir estas cosas-ideas como las siguientes.

Cuando aquella asamblea, aquella ponencia terminó de consensuar, bien que mal, pero más bien que mal, un texto, Chus Viana, con el gracejo que le caracterizaba, dijo: "Bien, bien, ¡en Carrera de San Jerónimo os esperamos!". Como diciendo: "Esto ha salido de aquí -alguno quizá lo recuerde, alguno que sea un poco más joven que yo-, pero luego esto pasará por donde tiene que pasar".

Pero, al mismo tiempo, a mí me decía Chus Viana -para que veamos cuáles eran los conceptos de la época-, Chus Viana me decía: "Mira, Carlos, yo concibo esta autonomía de la que estamos hablando, qué te diría yo... (éstas son palabras textuales), yo pienso en un gobernador de un estado federado de los Estados Unidos que es capaz de conmutar penas de muerte, es capaz de negar aterrizar a un avión de un jefe de estado extranjero en un aeropuerto de su Estado...”. Lo decía gráficamente en estos términos, para significar hasta qué punto él concebía la profundidad del autogobierno surgido de un Estatuto.

Y, hombre, si hoy pensamos en conmutar penas de muerte o negar su entrada en un aeropuerto de Euskadi a un jefe de estado extranjero, por emplear el ejemplo gráfico que él empleaba (no digo que sea el más riguroso ni el más relacionado con nuestro ámbito competencial), pues, creo que hallaríamos una cierta distancia.

Éstos eran los que en aquel momento pusieron una gran cantidad de objeciones al contenido potencial del Estatuto, que fue objeto de esa negociación a la que me refería.

Desde el 22 de junio, en que se produce este acuerdo con el Presidente Suárez, se constituye esa comisión técnico-política de alto nivel (estábamos en dos salas, en dos despachos contiguos), su meritoria labor, la de aquella comisión, no necesito realzarla una vez más, porque fue aquella una negociación maratoniana, en plena canícula de julio.

Hay que agradecer a nuestros compañeros del Partido Socialista, de Euskadiko Ezkerra, que en aquel momento especialmente estuvieron tantas veces en el Hotel Palace esperando a que evacuáramos las consultas necesarias, porque no estaban todos ellos precisamente en esa negociación paralela (vamos a llamarle así).

Y en circunstancias ciertamente dramáticas para quien les habla, después de innumerables viajes de ida y vuelta, se llegó a un acuerdo, justamente cuando la Comisión del Congreso tenía ya su plazo establecido para ver terminada su labor. Es decir, fue un trabajo contra reloj.

Yo he dicho que las especificidades del texto que se aprobó, y que se aprobó después en el Congreso, eran notorias, frente a lo que calificamos coloquialmente luego como "café para todos" a la hora de desarrollar el resto.

Hay que pensar que el Estatuto vasco fue un adelantado, ¿verdad? Anecdóticamente, ya todo el mundo sabe cómo esta Autonomía es la decana de las Autonomías, 
incluso porque tuvieron el acierto, en el Consejo General Vasco, de que Echevarría fuera en un avión llevando el texto y adelantándose a cualquier otro proyecto. Pero, en aquel momento, lo que concitaba la atención -dicho sea con todo respeto a otras Comunidades- era el caso vasco, y el caso catalán fundamentalmente. Hasta el punto -y esto también está relacionado con la especificidad a la que me refiero- de que por lo menos en dos ocasiones desde el Gobierno central se me sugirió una posibilidad, y era que el caso vasco se adelantara a todo el proceso autonómico, con una restauración del Estatuto del 36.

Concretamente lo hizo Pérez Llorca, que era Ministro de la Presidencia, y no sé si estaba con él otro Ministro, y después ya, formalmente, y antes de que este proceso al que me estoy refiriendo avanzara, fue Antonio Fontán, a la sazón ya Ministro de Administraciones Territoriales (creo que era la denominación de su cargo en aquel momento), que me llamó explícitamente para hacer esa propuesta.

Ante esa propuesta, yo debo decir que, por un lado, advertimos que tenía sus ventajas, en cuanto significaba el reconocimiento de una singularidad para lo que en la propia Constitución además está definido como "nacionalidades y regiones", y dentro de las primeras era una atención prioritaria la que se daba al caso vasco.

Tenía otros inconvenientes, porque en el Estatuto del 36, pues, entre otras cosas, no se contemplaba un procedimiento de participación de Navarra por la expresión de sus ciudadanos y ciudadanas, sino que estaba sometido al tortuoso procedimiento de unas mayorías cualificadas, etcétera, como cualquier otra provincia. Y, segundo, porque el ámbito competencial, fíjense ustedes, nos parecía absolutamente inferior al que la realidad política de nuestro país demandaba en la nueva situación, en la que, sin duda, la eclosión de los sentimientos nacionales y de la demanda de autogobierno había sido evidente.

Entonces, se desechó, entre otras, por estas consideraciones, ese procedimiento, y se siguió con el que estoy señalando, de manera tal que el asunto siguió su curso en el Congreso, y, como he dicho antes, tuvo un respaldo la negociación que se dio de facto y se formalizó en esa doble comisión, en esa doble instancia negociadora acordada con el Presidente del Gobierno a la que me he venido refiriendo.

Las especificidades de este Estatuto son evidentes, creo que nadie las niega. ¿Por qué invocar los derechos forales en cada competencia que se adivinaba problemática en cuanto a su alcance, sobre todo en el caso de generalizarse? Evidentemente, por dar una vía específica al Estatuto vasco. ¿Por qué esa disposición adicional, que fue una puerta abierta a una interpretación extensiva y nunca restrictiva, eso es una obviedad?

¿Por qué en el repertorio competencial de este Estatuto aparecen cosas que no aparecen en otros Estatutos? ¿Por qué se habla de un convenio de la Seguridad Social, aunque se quiera discutir qué significa el contenido de ese convenio, evidentemente, en una interpretación extensiva? Y ya veremos luego por qué, si ustedes quieren, cabe una especificidad importantísima que algunos hemos reivindicado de una manera constante. 
¿Por qué en el Estatuto catalán, por poner un ejemplo, las competencias de empleo, y en general las socio-laborales, tienen unos límites establecidos explícitamente que no existen en el Estatuto vasco y que justifican nuestra constante demanda en competencias de carácter socio-laboral y concretamente de empleo, etcétera? Porque, evidentemente, hubo una restricción deliberada en otros Estatutos que no existió en el Estatuto vasco.

Nosotros argumentamos en aquel entonces, para que se produjeran estas especificidades, con toda suerte de argumentos, de manera que yo pretendo una interpretación auténtica porque estaba allí, y porque empleé esos argumentos con otros compañeros más competentes que yo que estaban en esa comisión técnico-política de alto nivel, que nos mandaban los embolados luego al otro despacho, al Presidente Suárez y a mí mismo.

Pero nosotros, por ejemplo, argumentábamos, y éste es un argumento que yo creo que ratificarán gentes que estuvieron en esa negociación, que, si históricamente el Concierto Económico era, digamos, el receptáculo de todas las recaudaciones coercitivas del Estado (impuestos, exacciones fiscales y parafiscales, o en general recaudaciones coercitivas del Estado con el sentido finalista o con el sentido general de un impuesto), cuando surge el nuevo fenómeno de la Seguridad Social y de las recaudaciones coercitivas derivadas de ese y otros fenómenos, nosotros decimos: "Si hubiera habido un tracto histórico sin ningún salto en el vacío, sin ninguna irregularidad, si ningún proceso abolitorio, pues, este país, lógicamente, habría aspirado a eso".

Y ése fue, en pocas palabras, el argumento que prevaleció para que aparezca algo tan singular en este Estatuto cuando se habla de un convenio para la gestión del régimen económico de la Seguridad Social, que es cierto, nosotros aceptamos que no podía ser un sistema absolutamente diferente, que no tuviera unas homologaciones básicas en las prestaciones y en las recaudaciones coercitivas, digo una vez más, etcétera, etcétera, y que hubiera unos fondos de solidaridad, etcétera. Porque nosotros, por el hecho de querer un autogobierno, no queríamos ser menos solidarios que los demás, porque hay demasiado costumbre de confundir solidaridad con poca afición al autogobierno, y no tiene nada que ver una cosa con la otra.

Entonces, ésta es la historia, ésta es la historia, y ésta es la desesperación que a algunos nos va asaltando a medida que va transcurriendo el tiempo y nos encontramos con que "eso no puede ser, porque lo pedirían todos, porque eso es imposible generalizarlo en las 17 Autonomías”, etcétera, etcétera, etcétera.

Y yo creo que vale más que mis pretendidas interpretaciones auténticas, pues, la observación de lo que gentes menos sospechosas que yo dicen en la época, y lo digo sin ánimo de recordar a nadie pecados pasados.

Compañeros socialistas, en vuestro programa del año 80 vosotros demandáis, con la misma claridad y firmeza que nosotros, pues, un sistema de la Seguridad Social autónomo y una caja autónoma, decís textualmente en el programa del 80, y competencias de empleo, y un instituto de crédito oficial, etcétera, etcétera, etcétera. 
Claro, pasan los años, y cuando esto se va estancando... Y un día a Felipe González le recuerdo eso y me dice: "Carlos, pero es que, claro, si yo recojo todos los programas, me tiene que sumar cien, y entonces me sale más de cien”. Así, con ese gracejo habitual de Felipe, pues, zanjó la discusión. Pero de todo esto yo doy mi palabra de honor que son las cosas tal y como yo las he ido viviendo y como las tengo que repetir aquí, que creo que para eso se me pide que venga.

El espíritu de aquella negociación fue, por estos detalles que cito, bastante especial. Hombre, hay cosas que también tienen su significación, y perdonad porque os toque ahora un poco tangencialmente también, compañeros socialistas.

El leit motiv de la campaña electoral de Euskadiko Ezkerra fue: "Estatuto, un marco autónomo de lucha de clases”. ¡Casi nada! Hoy estamos hablando de administrar algunas competencias en materia socio-laboral frente a resistencias numantinas del Estado, y el leit motiv de parte de vuestro actual partido en aquella época era (repasad las hemerotecas), ni más ni menos, "un marco autónomo de lucha de clases", que ya no tienen ni los estados más nacionalistas que componen nuestro entorno geopolítico.

Esto no quiere ser una broma; quiere ser una evocación, insisto, de la concepción que circulaba, desmesuras electorales a un lado, en las gentes que participaron en aquel proceso, de las que evacuaban consultas con nosotros en el Hotel Palace en Madrid mientras se negociaba el Estatuto, y que luego trasladaban a la ciudadanía en sus programas electorales, en sus explicaciones públicas, este tipo de cosas. Lo digo como aspectos sintomáticos, como podría contar otras muchas cosas.

Hombre, cuando Felipe viene en la campaña electoral primera (no sé si fue la primera) y se produce aquel famoso "espíritu de Anoeta", Felipe dice también algo muy importante. Dice: “Todo lo que quepa en el Estatuto va a Misa”, más o menos textualmente. Y, señoras y señores, todo lo que quepa en el Estatuto no. Lo que cabe, no va a Misa.

En el Estatuto caben interpretaciones restrictivas y extensivas, eso es indudable, y la bendición o la prueba del agua regia del Tribunal Constitucional la pueden soportar igual, en ocasiones, una interpretación extensiva que una restrictiva (más bien la restrictiva, sobre todo con Presidentes como el que se nos descuelga ahora con esas declaraciones de patriotismo constitucional). Pero lo que sí es claro es que las interpretaciones pueden ser extensivas y restrictivas en un texto legal que, por su carácter básico, tiene que incurrir necesariamente, e incluso fue un recurso inevitable, como siempre que se negocia, en conceptos jurídicos indeterminados.

No puede detallarlo todo un texto básico, y el recurso de un texto básico siempre son los conceptos jurídicos indeterminados. Y los conceptos jurídicos indeterminados se remiten en tantas ocasiones a la voluntad política y a la interpretación extensiva o restrictiva derivada de la misma.

Por poner un ejemplo muy gráfico, que no es quizá el que más pueda interesar, si en un Estatuto -y en este hay indicaciones de este tipo- se dice que tal competencia, por ejemplo de puertos, será del Estado y no de la Comunidad Autónoma si hay una decla- 
ración de interés general, pues, hay dos actitudes políticas: declarar todos los puertos de interés general, o no declarar ninguno. Y, desde luego, ambas decisiones, que tienen una trascendencia, como puede observarse, notable en el autogobierno concerniente a esa materia, pues, reciben la bendición constitucional del tribunal.

De manera que sin poner un ejemplo tan gráfico, pero refiriéndome a cualquier materia, en mayor o menor medida caben siempre, sobre todo recurriendo a los conceptos jurídicos indeterminados, que son de diversa índole (las coordinaciones, los "sin perjuicio", etcétera, son numerosísimos)...

Y ahí es donde se produce una degradación progresiva, que va alcanzando cotas alarmantes a medida que pasa el tiempo y que parece que va a llegar al paroxismo en el momento actual, cuando esos conceptos indeterminados son aprovechados en las leyes básicas. Que nosotros, ingenuamente, sin duda, entendimos y hablamos que serían leyes básicas, qué sé yo, en materia educativa las que garantizan los grandes principios de la libertad de enseñanza, de la libertad de cátedra, etcétera, etcétera, recogidos en sus correspondientes leyes básicas, y luego nos encontramos con que los recorridos curriculares, y hasta casi los uniformes de los estudiantes, aparecen como materias susceptibles de incluirse en legislaciones básicas.

Éste es, para mí, el principal problema, porque la paralización competencial, si vale el término, a través de enervar esas competencias que están en el Estatuto (no en la Comisión de Transferencias, están en el Estatuto), pero que quedan invalidadas o neutralizadas si no hay la transferencia de recursos y de medios materiales para ejercerlas, que es lo que sucede...

Porque ahí perdemos perspectiva: las competencias son nuestras por el Estatuto; el problema es darles operatividad con la transferencia de recursos humanos y materiales. Y ahí es donde tiene la sartén y el mango el Estado, y, como puede mantener cómodamente el statu quo, sencillamente está invalidando e incumpliendo el Estatuto, porque las competencias están establecidas para la Comunidad Autónoma en tantos casos en los que suscribo de "pe a pa", como mínimo, los informes de este Parlamento del año 93 y 95, y eso me evita referirme a materias más concretas, y suscribo de "pe a pa" el informe de la Vicepresidenta del Gobierno, reciente.

Están incumpliendo la ley, están incumpliendo la ley porque las competencias son de la Comunidad Autónoma, y están valiéndose de tener la iniciativa inapelable a la hora de proveer a la transferencia de recursos para que puedan ejercerse en la práctica, desde el poder central.

En aquella negociación, y perdóneseme que vaya a veces a salto de mata -procuraré no extenderme más de lo debido, y, si no, me llama la atención, Presidenta-, ya que me he referido a especificidades, hubo puntos difíciles de esos que con Suárez acordé que pasaran de la comisión técnico-política de máximo nivel, a la que a veces íbamos para ver cómo iban las cosas, porque allí se estancaban en un pulso que fue muy duro y muy difícil... 
La complejidad técnica de estas cosas -también hay que reconocerlo- también explica que las cosas no se resolvieran con facilidad, de manera que yo no estoy hablando aquí echando la culpa de todo a la misma gente siempre. Las cosas eran, por sí mismas, difíciles.

Pero, entre esos puntos que fueron traídos para el desbloqueo al que me he referido antes, estaban materias como la educación, la Policía, la Seguridad Social, el Concierto (que también dio su guerra, pero sobre todo la dio en su desarrollo, más que en su plasmación en el Estatuto), la cuestión navarra, por supuesto (que para nosotros era una cuestión fundamental, aunque se haya perdido toda sensibilidad en tantos casos en relación con la misma con posterioridad), el problema de la televisión, etcétera.

El que crea que en aquella primera época las cosas fueron fáciles también se equivoca. Fueron muy duras. Y yo quiero recordar que, primero, en la negociación en casi todas estas materias se abrió el portillo ese del reconocimiento del derecho histórico foral para permitir una interpretación que incluso pudiera evadirse de los corsés que la legislación general básica pudiera establecer y de las dudas constitucionales que pudieran surgir. Esto es así, y desde luego lo digo con plena convicción, aquí y donde sea.

Como decía antes, en la educación, cuando se hablaba de "sin perjuicios" como el del artículo 17 de la Constitución, o el artículo 149.1.30, si no me equivoco, se estaba hablando de esos grandes principios que tendrían su desarrollo en leyes orgánicas. Una cosa es desarrollar el principio básico de la libertad de enseñanza, o de la libertad de cátedra, o de la universalidad de la enseñanza, en una ley básica, y otra cosa es descender a las cosas a las que se está descendiendo.

En lo concerniente a la Policía, éste fue un tema delicadísimo. En los primeros contactos que tuvimos ya en el Consejo General Vasco yo recuerdo cómo Martín Villa, a la sazón Ministro de la Gobernación..., pues, desde luego, su concepto era que la Policía tenía que ser una policía dirigida desde el Gobierno central.

Eso fue evolucionando, porque, desde luego, a nosotros ni se nos pasaba por la cabeza, y en el round final de aquella negociación en el despacho, en el que estuvo Suárez, estuvo Ibáñez Freire, al que llamó Suárez en un momento determinado, y no sé si vino alguien más, al final se aceptó que hubiera unas materias... Yo, desde luego, consideré que eran materias tasadas, luego el Gobierno central se aferró a que no era un numerus clausus, si vale la expresión, sino que eran materias extra o supracomunitarias, como inmigración, fronteras, pasaportes, etcétera, etcétera, etcétera. Pero, desde luego, nosotros siempre entendimos que con voluntad política, y con una interpretación extensiva derivada de esa voluntad política, naturalmente podría constreñirse la función de los cuerpos estatales a las materias allí citadas. Eso yo creo que tiene su lógica.

Luego la lógica ha sido otra. La lógica ha sido al margen de las allí citadas, y no por casualidad, que a nosotros nos hacían concebir una presencia de cuerpos policiales aquí, pues, discreta (para fronteras, "equis"; para inmigración, tantos), pero nunca $5.000 \mathrm{o}$ 6.000 policías. Y lo digo con todo el respeto a esos cuerpos, como puedo tener el mismo respeto a cuerpos de inspectores de Hacienda o de lo que sea, que fueron sustituidos. 
Y nosotros, desde luego, defendimos en los dos primeros gobiernos (después del Consejo General Vasco tuve el honor de presidir uno entero y otro mutilado), nosotros siempre defendimos el principio de la sustitución. Y yo creo, con perdón de aquel a quien corresponda, que el gran fallo fue el de refugiarse en términos ambiguos de "adecuación" en vez de "sustitución", de manera que, sin duda con la mejor voluntad de ir desarrollando cosas y de no colapsar procesos de desarrollo (quizá una concepción más acertada que la mía), se pasó del término "sustitución" al término "adecuación".

Y así tenemos hoy un maremágnun aquí y una confusión y una orgía de cuerpos policiales que yo no digo que no sean necesarios; lo que yo digo es que, para mí, tenía que ser una policía autónoma, salvo en los casos tasados. Y ése fue el espíritu, desde luego, para mí, de aquella negociación, tanto en la comisión mixta de máximo nivel, técnico-política, como en la solución final, en el buen sentido del término, que le dimos en el despacho del desbloqueo.

En lo concerniente a la Seguridad Social yo ya he dicho cuál fue nuestra interpretación y nuestra argumentación. Desde luego, que haya una transitoria hablando de un convenio quiere decir algo.

En lo concerniente a... Perdóneseme, porque yo no tengo muy buena memoria para citar cosas textuales, pero que son las que acreditan las afirmaciones que uno hace...

Ya he dicho que en materia socio-laboral el Estatuto catalán establece en materia de ejecución de la competencia laboral que "quedan reservadas al Estado todas las competencias en materia de fondos de ámbito nacional y de empleo”, y esta cláusula motiva que Cataluña tenga que aceptar una transferencia, por ejemplo, en materia de formación profesional ocupacional en las condiciones que establece el Estado, como mera delegación administrativa. A este campo pertenecen aspectos como la prestación por desempleo, el Fondo de Garantía Salarial, promoción y gestión de empleo, formación profesional ocupacional, etcétera, etcétera.

Pero en virtud del llamado principio dispositivo, en virtud del cual cualquier Estatuto puede asumir cualquier competencia que no esté expresamente atribuida al Estado, en la Comunidad Autónoma vasca eso no está reservado al Estado, no está explicitado en el Estatuto, y de ahí nuestras disconformidades al respecto. Y, desde luego, ése fue el sentido de la redacción del Estatuto en el proceso negociador al que reiteradamente estoy haciendo alusión.

No voy a referirme al caso navarro, que fue probablemente... El caso de Navarra fue el más duro, pero, en fin, que tiene su curso y que, como siempre suele suceder cuando se trata de resolver una cosa racionalmente, pues, fue objeto de una negociación que ya empezó en el proceso constitucional, en el que desde la derecha navarra se nos pedía inicialmente una mayoría cualificada de tres cuartos de navarros para participar en un proceso estatutario, y generosamente redujeron eso a dos tercios después. 
Hubo una reunión en la sede de Castellana con el entonces Vicepresidente del Gobierno, Abril Martorell (estoy hablando del proceso ya constitucional, previo a todo esto), toda la plana mayor del entonces Gobierno, y una plana mayor también del Partido Socialista. Allí estaban Enrique Múgica o Benegas, entre otros; estaba también, si no me equivoco, Urralburu por Navarra, y estaban por UCD, desde el Vicepresidente del Gobierno en aquel momento, Abril Martorell, que era el que lidiaba con todos los "marrones", pasando por Landelino Lavilla, Herrero de Miñón, etcétera, etcétera. Es decir, lo más granado. Y estuvimos Ajuriaguerra, Iñigo Agirre y yo en esa negociación.

Y después de que se rompiera en varias ocasiones prácticamente la negociación... Abril Martorell era un especialista: cuando ya se estaba llegando a un acuerdo, tenía una llamada telefónica y decía: "Perdonadme un momento...", y entonces volvía con otro papelico y decía: "Se me ha ocurrido una cosa cuando estaba ahí afuera...", y entonces empezaba de cero y aquello era el cuento de nunca acabar.

Pero al final, después de un proceso traumático, porque supuso la ruptura de muchas cosas... Supuso la ruptura de la propia UCD (de ahí surgió UPN para combatir el nacionalismo vasco, lo dice en sus propios estatutos), y se produjo una ruptura en nuestro propio mundo nacionalista, al no comprender que se llegara a una solución que, por cierto, era mucho mejor que la que alguno de sus adalides en el año 36 había asumido. Porque en el año 36 no había vía para la participación de Navarra a través de una mayoría de esos órganos forales y un referéndum también mayoritario. Era como Soria o como Santander: requería mayorías especialísimas, como las que quería resucitar la UCD en esa negociación.

Bueno, éste fue uno de los puntos muy espinosos, que yo traigo a colación aunque no parezca relacionado con el desarrollo estatutario que hoy se contempla aquí, pero, ¡ojo!, sí con el problema político que existe en este país y que -permítaseme expresar también esa opinión-, si un día hay que resolverlo racionalmente, civilizadamente, de la única manera en que se pueden resolver los problemas, tendrá que ser tenido en cuenta también.

Porque, miren ustedes, en la cuestión navarra se pasó desde la transacción a la que llegué yo con Antonio Fontán, para que en los mapas de televisión no aparezca separada (en aquella época, con los conceptos de la época) Navarra del resto de Euskal Herria, a que luego pusieran una raya discontinua (porque esto parece de chiste, pero esto es así, pero eso revela también con qué finura se hila a la hora de incidir en las conciencias y las percepciones de la gente cuando miran una televisión), a dar el mapa del tiempo después de pasar por Zamora, saltando desde Gipuzkoa a Cataluña, ¿verdad?

Entonces, de pretender seguramente un autogobierno compartido, sin ninguna especificidad para la personalidad histórica y política de Navarra, que proclamamos algunos como los primeros, a decir que no hay nada y que no puede haber nada, y que este problema nada tiene que ver con Navarra, etcétera, salvo para las acciones concertadas del Ministerio del Interior o para las declaraciones episcopales, etcétera, bueno, 
yo creo que hay un abismo. Y alguna idea, si hay que hacer un replanteamiento de la situación, que yo creo que hay que hacerlo, habrá que verter a este respecto, conciliadora entre posturas que, a mi entender, como siempre, en ocasiones son extremas y son las que se complementan más perfectamente.

Mis compañeros socialistas esbozan alguna sonrisa, pero yo hice con ellos muchos mítines en aquella época defendiendo el Estatuto vasco, incluso cuando estaba ya sentenciada la no participación, porque la ley D'Hondt dio a la UCD, por los pelos, una mayoría de parlamentarios que se pronunciaron en sentido contrario, a pesar de que éramos mayoría las fuerzas, de un signo u otro, entre ellas el Partido Socialista, partidarias de un Estatuto conjunto, e incluso los grandes mítines de cierre de la campaña del Estatuto se hicieron tanto aquí como en Navarra.

Yo participé en ellos con los principales representantes socialistas, y también creo que el socialismo tiene en eso una misión importantísima para una reflexión histórica en la que veamos todos cuáles han sido nuestros errores al conducir esta cuestión, que para mí -lo digo sinceramente- es la más intrincada y la más sensible del llamado "problema vasco".

Perdóneseme esta digresión, pero, entre otras cosas porque soy navarro, me van a permitir la licencia. Que no es licencia, porque es uno de los temas escabrosos de la negociación del Estatuto.

Bueno, no quiero aburrirles más, pero entre las especificidades que hay en el Estatuto, para no hablar a humo de pajas, está, por ejemplo, la televisión. O sea, frente a la concesión de canales, etcétera, por parte del Estado, aquí se establece, lisa y llanamente, el derecho a tener sus propios medios de comunicación o la televisión. Pues ¡no crean ustedes que fue fácil! Textualmente, Calvo Sotelo se negaba entonces a que el espacio radioeléctrico disponible estuviera a nuestra disposición, y yo tengo testigos. Entre otros testigos, por cierto, estaba Juan Porres, que hoy viene por aquí, me parece; estaba Labayen, estaba Castedo...

Y yo le dije a Calvo Sotelo, porque ya era un punto muerto del que no salíamos, a pesar de esa rotundidad del Estatuto al establecer -cosa que no hacen otros Estatutos- ese derecho propio y no concesiones de terceros canales, etcétera: "Bueno, pues investigaremos el espacio radioeléctrico y pondremos la televisión en marcha”. Y Calvo Sotelo dijo, literalmente: "Pues irá la Guardia Civil". Y yo, perdóneseme la jactancia, le dije: "Pues habrá 100.000 vascos delante de la Guardia Civil”. Y así se puso en marcha la televisión.

De manera que, como dijo el poeta, "cualquier tiempo pasado no fue mejor". Las cosas han ido saliendo a veces con esos pulsos y esos órdagos que tantas veces se nos han reprochado a los que hemos tenido alguna responsabilidad en este país, pero así salieron las cosas.

Y, ¡cuidado!, el primer Estatuto y el primer despliegue de la Ertzaintza, etcétera, etcétera, no salió por casualidad, después de que viniera aquí el Presidente Suárez, precediendo a la visita del Rey. Porque algunas cosas se han movido por impulso regio, y el 
Rey quería venir a Euskadi hacía mucho tiempo, y algunos, aunque no era costumbre de la época, le dijimos que era mejor que no viniera hasta que no se devolvieran cosas que por decretos de guerra había suprimido Franco, etcétera.

De manera que todo esto tiene su historia, y, si ustedes me lo permiten, por mi condición, por mi provecta edad y paso por estas vicisitudes, quizá lo digo para que tengamos un poco de moral, y esperemos que quizá las cosas puedan arreglarse también, porque nunca han sido fáciles.

En definitiva, yo recuerdo estos puntos que fueron difíciles, por no citar todos. Más perplejidad me produce que algunas competencias menos discutibles en aquel momento todavía, que no fueron objeto de una transacción tan equilibrada como la que pretendimos en estas otras materias, sigan siendo materia controvertida: que la investigación no tenga una salida; bueno, que el empleo -ya he dicho-, que el deporte, que las federaciones, que las selecciones deportivas... Si en aquella época a nosotros nos dicen que todo esto iba a ser materia de esta dificultad, no lo habríamos creído.

Y, para no extenderme, ya he dicho antes que me remito a los informes que el propio Parlamento Vasco hizo en cuanto al repertorio de competencias pendientes.

Yo, cuando leo el informe de la Vicepresidenta del Gobierno y veo en qué términos se cruzan las correspondencias hoy, y nos dicen que no quedan 37 materias, sino que quedan ocho, etcétera, etcétera, la verdad es que siento un gran desaliento, no lo puedo negar, porque me parece que estamos dando pasos atrás muy preocupantes.

Y en conclusión, y termino, yo creo que ahí no tengo más remedio que ser pesimista, y a la vez optimista. Yo creo que tan difícil pudo ser en su día el tránsito de un sistema autoritario a un sistema en el que se permitía, aun en circunstancias difíciles, este tipo de cambios y negociaciones, tan difícil o más fue aquello, que hoy hacer un replanteamiento del autogobierno.

Estamos en otro momento histórico, en circunstancias diferentes. Nadie, ni nosotros ni ustedes, tiene las imperiosas exigencias del sentido de la responsabilidad que entonces condujeron a que los compromisos tuvieran que ser tan medidos y equilibrados. Estamos en otro momento histórico, porque también la experiencia nos enseña a todos para hacer las cosas mejor.

Yo creo que es imposible, si se me permite la expresión, "destejer" todo ese intrincado tejido de leyes básicas al que me he referido antes, que constituyen un corsé a mi entender ya insuperable para el desarrollo potencial que en su día vimos en el Estatuto de Autonomía. Creo que, lamentablemente, esto ha impedido, como he sugerido antes en euskera, el alcance del autogobierno potencial en el contenido, y la dimensión de la misión histórica que pudo tener el Estatuto ha quedado notabilísimamente restringida por ello, y yo creo que estamos en el momento de un replanteamiento valiente.

Ya sé que es complicado, pero, insisto, no fueron menos complicadas otras cosas que se hicieron en su día de toda la cuestión del autogobierno. Y, desde luego, con la experiencia que tenemos, de la indefensión en que el débil se encuentra cada vez que se produce un 
punto muerto y se mantiene el statu quo o la interpretación restrictiva del fuerte, que es el poder central, a pesar de todas las instancias jurisdiccionales que se quieran citar...

Yo no voy a hacer aquí una ironía fácil diciendo que qué sería si tuviéramos que remitirnos al rigor jurídico y a la probidad de los jueces marroquíes para desbloquear el asunto de Ceuta o Melilla, ¿verdad? Alguien me dirá: "No, son cosas muy diferentes". Bueno, diferentes hasta cierto punto.

La verdad es que con esta experiencia yo me reafirmo en algo que para nosotros es la última ratio, no sólo para optar a otras fórmulas políticas democráticamente, sino también para tener un asidero, el asidero del débil en estos contenciosos, que es el derecho de autodeterminación de un pueblo, para que, si no se cumplen los compromisos, si no se cumplen los pactos, si las fórmulas que se interpretaron de una manera determinada son interpretadas también después, al socaire de la fortaleza del fuerte, de una manera determinada contra la opinión del débil, sin que éste salga de su indefensión, es la última ratio, como digo, para resolver también esos problemas.

Y aquí termino yo, echando, perdóneseme, este cuartillo a espadas a mis propias convicciones.

Bai, eskerrik asko, Garaikoetxea lehendakari jauna.

A continuación abriremos un turno de grupos. Les recuerdo que para poder cumplir, en la manera de lo posible, el orden y el horario que tenemos establecido, largo horario de trabajo de la Comisión, nos quedarían tres cuartos de hora para empezar ya con el siguiente compareciente. Luego, tal y como les he expuesto al comienzo de la reunión, lo que abriríamos sería un turno de preguntas a los distintos miembros de la Comisión, para que por tiempo máximo de cinco minutos puedan hacer preguntas o solicitar aclaraciones a los extremos que han sido objeto de comparecencia, y poder así dar oportunidad al interviniente para responder, bien puede ser al final, después de formuladas todas las preguntas, o de uno en uno, como él prefiera.

Pero sí les ruego, por favor, en la medida de lo posible, brevedad y colaboración para poder cumplir el calendario que tenemos establecido.

Beste barik, taldeen txanda zabalduz, Ezker Batuako ordezkariak dau hitza, Antton Karrera jaunak dau hitza.

EI Sr. KARRERA AGIRREBARRENA:

Bai, lehendakaria.

Nik ez dut galderarik egingo, bakarrik eskerrak eman Carlos Garaikoetxeari berak Estatutoa sortu zenean eta ondoren bizi izan zituen gorabeherak, hain gorabehera garrantzitsuak hemen argitu dizkigulako. Batzuk bagenekizkien, baina guztiak ez, 
eta nik uste dut berak egin duen agerpenean nabari gelditu direla, nola eztabaidatu zen Estatutua eta nola sortu zen paktua eta bere garrantzia. Eta gaurko egunean, baita ere, hori nola ez den betetzen. Ni horrekin konforme nago. Nik, galderarik ez diot egingo, eskerrak ematen dizkiot eman dizkigun argi garrantzitsu horiengatik, eta besterik ez.

La PRESIDENTA:

Bai, Garaikoetxea jauna, gura badozu...

EI Sr. GARAIKOETXEA URRIZA:

Bueno, mila esker, bakarrik.

La PRESIDENTA:

Txandarekin jarraituz, Batasunako ordezkariak, Salaberria jaunak, dau hitza.

EI Sr. SALABERRIA SANSINENEA:

Bai, eskerrik asko.

Egun on, Garaikoetxea jauna.

Bueno, bistan da gure irakurketa eta gure balorazioak Gernikako Estatutuaren inguruan ezagunak direla. Guk, garai hartan bezala, gaur ere garbi adierazten dugu gure ustetan aukera historiko bat izan zen moduan, gure irudiko, zapuztutako aukera bat izan zela, nolabait esatearren, argi dugulako Gernikako Estatutuak ez zuela orduan Euskal Herriak eskatzen zuen eta behar zuen abiapuntu demokratikoa finkatu; eta, beraz, gure ustez, Gernikako Estatutua ez da marko politiko legitimo bat eta ez da marko politiko demokratiko bat, ez?

Hain zuzen ere, guk zure interbentzioan ulertu dugu edo ulertu dut -eta egin behar ditudan bi galderak, hain zuzen ere, ideia horietan kokatu nahi ditut-..., 'renuncia' hitza aipatu da, alegia, uko egitea negoziazio-prozesu hartan, eta baita ere, agian ez hitz horrekin, baina interbentzio osoan zehar ulertu dut nolabaiteko iruzur-sentsazio bat badagoela, ez?, orduan paktatu zena, nolabait, ez dela errespetatu egin eta, beraz, orduan sortutako paktu hori edo akordio hori bete gabe eta, bueno, Espainiako botereek edo Espainiako Gobernuak kasu honetan eta gaur egun ez dutela errespetatzen orduko paktu hori, ez? Orduan, uko-egite horretan eta iruzur horretan guk hor kontraesan bat ikusten dugu, hain zuzen ere amaieran planteatu duzun funtsezko ideia batengatik: planteatu da, beraz, autodeterminazioan oinarritutako abiapuntua dela herri honek behar duena. Gure galdera da, bueno, bistan da erabil 
daitezkeen argumentuak izan daitezkeela eta beti izaten direla testuinguru politiko hartan gauzak oso zail zeudela, frankismoaren amaieraren egoera zela, Estatuaren aldetik bere indarrezko posizio erabateko batetan inolako aukerarik ez uzteko beste aukera batzuetarako, bistan da testuingurua aipatzen dela, baina gure galdera da zergatik garai hartan uko egin zitzaion autodeterminazio-eskubidearen planteamenduari, jakinda garai oso zailak zirela, zergatik, eta ez ote den orain baloratzen, hogei urte beranduago, nahiz eta askoz ere konplikatuagoa eta gogorragoa izango litzatekeela garai hartan halako hautu bat egitea, baina hogei urtetako perspektiba batetan ez al dugu ikusten hogei urte beranduago garai hartan autodeterminazioan oinarritu izan balitz abiapuntu hori hogei urte hauetako egoera oso bestelakoa izango litzatekeela eta gaur egun oso bestelako egoera batetan aurkituko zela herri hau? Hori izango litzateke lehenengo galdera.

Eta bigarren galdera ere, nolabait, zentzu horretan dihoa: uko-egite horretan aipatu duzu Nafarroaren gaia. Gure ustez ez da Nafarroaren gaia, da lurraldetasunaren gaia; alegia, Euskal Herria herri bakarra da. Zergatik uko egin zitzaion ez Nafarroa Gernikako Estatutuan sartzeari edo ez, zergatik uko egin zitzaion -autodeterminazioan oinarritu ez bazen ere- estatus politiko berri horretan, autogobernuaren estatus horretan, zergatik uko egin zitzaion lurraldetasunaren defentsari, ez? Zergatik Nafarroa?, zergatik ez Bizkaia?, zergatik ez Araba? Zertan oinarritzen da herri honen partizioa: Estatuak inposatzen duelako Nafarroa kanpo gelditu behar dela? Zergatik planteatu zen horrelako irtenbide bat, hogei urte beranduago ere ikusten denean, hain zuzen ere, eta zuk oso ondo adierazi duzun bezala, gatazka politikoaren zentroan kokatzen den gai bat dela, ez, alegia, ezin dela herri honetan abiapuntu demokratiko eta berri bat finkatu autodeterminazioan oinarrituta ez baldin badago Euskal Herri osoarentzat, herri bakar batentzat, ez?

Eskerrik asko.

La PRESIDENTA:

Zuzenean orain erantzuten dituzu, banan- banan? Bai? Zuk gura dozun bezala, e?

EI Sr. GARAIKOETXEA URRIZA:

Nahi duzun bezala. Zure esku.

La PRESIDENTA:

Ez. Nik, zuk gura dozuna; gura baduzu, orain, zuzenean erantzun. Garaikoetxea jaunak dau hitza. 
Bai, labur-labur erantzungo dut.

Bueno, lehendabizi zuk esan duzu Estatutu hau edo irtenbide hau ez zela gure herriak eskatzen zuena. Hori ez da egia, hori ez da egia. Garai hartan, esan dudan bezala, indar politiko gehienek hola erabaki zuten, parte hartu zuten partidu gehienek, eta bakar-bakarrik itunetik edo soluziotik kanpo gelditu ziren KASeko jendea, Blas Piñar eta Fraga Iribarne. Sentitzen dut, e?, ze momentu honetan da autonomista gogorrena, e?, baina horrek zerbait esan nahi du baita ere, zuen ondorioak atera ditzakezue.

Bigarrena. Zergatik ez genuen aurkeztu momentu hartan autodeterminazioaren aukera. Bueno, guk politika erreala egiten dugulako. Eta momentu hartan, egia esateko, gauza asko moderatu behar ziren. Zuk ondo dakizu..., bueno, zu oso gaztea zara, beharbada ez duzu gogoratzen, baina, zer egoeratan geunden garai hartan. Eta politika erreala egiten baduzu eta ez bakarrik, erderaz esaten den bezala, "brindis al tendido" botatzen baduzu, politika erreala horretan datza, momentu bakoitzean premiazko gauzak konpontzean. Eta lehen aipatu ditut nik gauza premiazkoenak: hizkuntzaren egoera, kulturaren egoera, azpiegiturak, espolio fiskala eta abar eta abar. Eta herri honen gehiengoak hala ulertu zuen, aurreratzea posible zela. Eta horregatik aukeratu genuen bide berezi bat. Eta, beste aldetik, bide oso berezia, zeren eta bazuen akordio amankomun bat Euskal Herrian zehar, bide forala. Eta bide forala mugagabeko bidea zen, gure ustez, eta posible da oraindik. Gero, egia esateko, Konstituzioan, hor erderaz esaten den bezala, "círculo vicioso" bat agertu zen, esaterakoan, Esparterok esan zuen bezala, "en el marco de", baina hala eta guztiz ere badakizu oraindik, borondate politikorik badago, posible dela bide horretatik aurrera egitea. Baina dena den, politika erreala egiten genuelako, e? Eta gure herria ez zegoelako txantxetan ibiltzeko. Zuk hilzorian bazaude ez duzu eskatzen "cordero al chilindrón" bat jateko, baizik eta momentu horietan digeritu dezakezuna, ezta?

Bigarrena, Nafarroako asuntoa. Begira, lehen aipatu dut 1936an Nafarroako asuntoa nola tratatzen zen -han zegoen nire adiskide Telesforo Monzón, e?-, eta garai har$\tan$ Nafarroa zen Santander edo Soria edo Logroño bezalakoa: sartzeko prozedura berdin-berdina zen. Gehiengo kualifikatu bat behar zuten, eta horregatik ezagutzen zuten zoritxarrez Nafarroan gehienak zirela, ba, ehuneko 75 onartzeko sarrera hori. Azkenean lortu genuen gehiengo normal bat. Eta momentu hartan guk aukeratu genuen herri honetan ikusi dugun estrategia errealista eta zuzen bakarra, hain zuzen, gehiengo bat lortzea eta gehiengo horren bitartez lurraldetasuna lortzea. Zergatik? PSOErekin gehiengo bat osatzen genuelako. Eta kasualitatez -eta gure herriak zorte txarra badauka batzutan-, gehiengo bat lortu genuen 1977an Nafarroan, baina zoritxarrez, ley D'Hondt delakoak eman zion gehiengo bat ordezkaritzan eskuindarrei. Eta eskainu batengatik edo horrelako gauza batengatik ez genuen lortu lurraldetasuna, baina hori zen estrategia errealista eta argi bakarra gauzak konpontzeko. Zuek bitartean, bueno, 
zuek..., zuen aitzinakoak, noski, ibiltzen ziren oihukatuz, "brindis al tendido" botatzen eta abar, esanaz "Estatu nazional bat", "autodeterminazioa" eta abar eta abar, baina politika erreala datza erabaki errealistak hartzean, ezta?, ez programa demagogikoak botatzean.

Bueno, barkatu, zure galderak gogorrak dira eta nere erantzunean argia izaten saiatzen naiz, baita ere.

Zure lagun batzuek momentu honetan gauza berbera proposatzen dute, orain gauzak askoz zailagoak direnean, e?, Aralarkoak eta abar eta abar, hogei urte pasa ondoren.

La PRESIDENTA:

Txandarekin jarraituz, Gorka Knörr jaunak dau hitza, Eusko Alkartasunaren izenean.

El Sr. KNÖRR BORRÀS:

Bai, presidente anderea.

Eskerrik asko Garaikoetxea lehendakariari.

Ez dut uste alderdikidetasunak behartuta dela esatea oso hitzaldi mamitsua izan dela zure partetik, baizik eta hemen ordubete inguru egon garelarik entzun duguna guztiz mamitsua dela esatea, nik uste dut guztiz zilegi dela. Eta ez dut uste, gainera, komisio berezi honetan ibili behar dugunik, batez ere momentu honetan eta garai hartako gertakizunak eta negoziaketak gogoratzen ari garela, ez dut uste merezi duenik eztabaida multilateral batean aritzea, baizik eta entzutea batez ere garai hartan testigu bereziak izan zirenak eta testigantza horien berri izatea gure kriterioak, gure irizpideak osatu ahal izateko, ezta?

Hala ere, gogoratu behar da..., zure lasaitasunerako esaten dut, ze "su renuncia" -'renuncia'- hitza erabili duzu, baina, nik uste, oso zentzu logiko batean, hau da, nik uste dut momentu honetan ere, garai hartan bezala, iritsi behar baldin badugu halako kriterio amankomun batera, akordio amankomun batera, izango da batzuek eta besteak, indar politiko desberdinek, ariketa bat egingo dugulako, hain zuzen ere, batzuen arteko kriterioa osatzeko, batzuen arteko akordioa osatzeko. Eta, noski, akordioak, ez bakar batenak baizik eta batzuenak eta gu guztionak baldin badira, batzuek eta besteok ez ditugu inposatu behar, orain batzuek eta 2002.ean aitortzen duten bezala, ezin dituztela bere kriterioa eta bere ideologia eta bere proposamenak inposatu; beraz, nik uste dut, zure lasaitasunerako eta gu guztion kriteriorako, nik uste dut esan beharra dagoela, ezta?, zerbait egingo dugu baldin eta kapaz baldin bagara halako aterabide amankomun bat bilatu ahal izateko.

Garaikoetxea lehendakariari esan behar diot berriro ere mamitsua izan dela guztiz. Iritziak beti libre dira, baina gertakariak, ordea, sakratu. Gertakariak hor daude, batez 
ere, eta nik uste dut horregatik eskertzekoa dela zure interbentzioa, ulertzeko gertakarien bitartez eta, nahi baldin baduzu, kontatu dituzun anekdoten bitartez, zer-nolako borondatea izan zen garai hartan emandako negoziazioan. Horregatik, nik uste dut hortik ere guk guztiok, ez bakarrik Eusko Alkartasunakoak, ikasi behar dugula, eta horregatik berriro ere eskerrak ematen dizkizut.

EI Sr. GARAIKOETXEA URRIZA:

Eskerrik asko.

La PRESIDENTA:

Txandarekin jarraituz, Alderdi Sozialistako ordezkariak, Eguiguren jaunak, dau hitza.

EI Sr. EGUIGUREN IMAZ:

Por nuestra parte, quiero agradecer también la intervención del señor Garaikoetxea, que nos ha parecido muy clarificadora e interesante.

Posiblemente discreparíamos de algunas valoraciones o consecuencias que extraía de los hechos que ha relatado, pero, en fin, no creo que sea la función de esta Comisión entrar en ese tipo de debates. En su día, cuando hicimos- me imagino que con otros grupos- estas solicitudes de comparecencia era precisamente para escuchar la versión o la opinión o la visión del tema por parte de quienes tuvieron un protagonismo especial en la negociación y elaboración del Estatuto, y en ese sentido nos sentimos plenamente satisfechos.

EI Sr. GARAIKOETXEA URRIZA:

Pues, muchas gracias, señor Eguiguren.

La PRESIDENTA:

Eskerrik asko.

Aurrera jarraituz, Alderdi Popularreko ordezkariak dau hitza galderak edo azalpenak eskatzeko. Leopoldo Barreda jaunak dau hitza.

EI Sr. BARREDA DE LOS RÍOS:

Muchas gracias, señora Presidenta. 
Yo quería en primer lugar, como es lógico, agradecer la comparecencia de don Carlos Garaikoetxea, agradecer su testimonio, que, evidentemente, no por subjetivo -como tienen que ser todos los testimonios- deja de tener un valor importante para todos los que estamos aquí.

Yo creo que ha sido un acierto de la Comisión comenzar por la comparecencia de quien entonces era Presidente del Consejo General Vasco y después fue Lehendakari durante algunos años, y también creo que es importante hacer algunas preguntas.

Yo creo que en su intervención, evidentemente, ha habido aspectos muy interesantes, ha habido aportaciones que yo creo que, lejos del dogmatismo con que se produce el debate político vasco, pues, aportan luz a algunos aspectos, por más, insisto, que estemos hablando de hechos... En fin, yo no soy partidario de esa mitomanía de algunos políticos vascos. Yo no hablaría de que los sucesos sean sagrados, señor Knörr. Yo creo que sagradas son otras cosas, y los sucesos, bueno, son subjetivos, y tenemos la visión subjetiva importante, la aportación del señor Garaikoetxea.

Yo quería preguntarle, reconociendo, por supuesto, esa subjetividad, que es con la que quedan todos los testimonios, si, cuando habla de que el Estatuto actual no es el firmado en el 79, no sería más exacto decir o reconocer que de algún modo se está exigiendo al Estatuto lo que nunca contempló como acuerdo. Una cosa es lo que cada cual planteaba en torno al Estatuto; otra cosa es poder decir que hubo acuerdo en la interpretación que uno hacía del Estatuto.

La pregunta que le hago es si ciertamente en torno a ese Estatuto, en el que había, como usted ha reconocido, desacuerdos importantes en los textos a tratar, planteados desde el Partido Socialista o desde la UCD, en torno al que se recurrió muchas veces, como es obvio, a conceptos jurídicos indeterminados, en torno al que cabían interpretaciones muy diversas, si realmente lo que se hizo, más que llegar a acuerdos en esas materias o en torno a las interpretaciones o a las reivindicaciones que usted nos recordaba aquí, si realmente lo que se hizo no fue recurrir a textos que permitían lecturas diferenciadas, y que, bueno, después viniese quien correspondiese a hacer los desarrollos.

Algunos hemos recordado aquí. Usted ha recordado el de la Policía, en el que, evidentemente, yo creo que la interpretación se ha aproximado mucho más a la que usted defendía en su momento, con los matices que queramos. En otras simplemente no hemos conseguido nunca casar interpretaciones, como el tema de Seguridad Social, ¿verdad? Pero, ciertamente, a mí me gustaría que usted se posicionara sobre si realmente no se buscaron espacios de encuentro, sabiendo que había discrepancias de interpretación respecto al alcance de los textos consensuados.

En segundo lugar, me ha parecido percibir, y me gustaría conocer su versión al respecto, una especie de impugnación de lo que se llamó el "café para todos" desde una perspectiva curiosa. Es decir, lo diferencial, lo propio, lo específico vasco, lo era, sobre todo, porque no era de otros. Si los techos competenciales de los demás se van 
elevando al cabo de veinte años, aquí se está traicionando el Estatuto vasco, o se está incumpliendo el Estatuto vasco, o se está haciendo algo diferente a lo que entonces pudiera estar previsto.

Bueno, me gustaría que nos aclarase a ver si sobre la mesa podía estar que, bueno, como nosotros teníamos más competencias en esto o aquello, el Estatuto era satisfactorio, y, en cambio, si otros alcanzaban ese nivel competencial dejaba de serlo, que es lo que yo he creído entender al comienzo de su intervención.

Bueno, ha reconocido usted que hay interpretaciones extensivas y restrictivas que pueden ser igualmente legítimas en torno a los textos. Por eso le he hecho yo la primera pregunta, evidentemente.

No ha recordado usted ninguna interpretación extensiva que se haya hecho del Estatuto. Ha mencionado el tema de puertos, que yo creo que evidentemente es una interpretación extensiva respecto al texto inicial del Estatuto, la actual situación y la que pueda llegar, porque la actual ya es extensiva.

Tampoco ha mencionado otras interpretaciones extensivas. Me gustaría saber si recuerda algunas más, más que nada porque yo sí recuerdo algunas, y me gustaría saber si realmente podemos ponernos de acuerdo en que se han hecho en pro y en contra.

Y sobre todo nos gustaría que usted recordase quién dio al traste con la LOAPA. Porque aquí mucho se habla de la LOAPA, pero hay que recordar que la LOAPA hubo un órgano constitucional que se ocupó de que no entrase en vigor y no trastocase el sentido del Estado autonómico presente en la Constitución y en los desarrollos estatutarios. A mí me gustaría que se recordarse expresamente, por el testigo histórico aquí presente, quién se ocupó de que la LOAPA no entrase en vigor, o por lo menos fuera derogada en todas sus partes sustanciales.

Y, como último aspecto, a mí me gustaría... Hombre, no ha hecho ninguna referencia..., ha hecho una referencia de pasada a otro momento histórico y otras circunstancias históricas. A mí me gustaría saber cómo valora usted estos veinte años, los cambios sociales y políticos que ha vivido el País Vasco; si, desde su perspectiva, el Estatuto actual (el Estatuto aprobado en el 79, para ponernos de acuerdo en a qué nos referimos) hubiera sido igual, o si realmente es algo sobre lo que tiene que incidir una evolución histórica que supone la entrada de España en la Unión Europea, por ejemplo, y otras pequeñeces como estas que han sucedido en estos veinte años.

Y, sobre todo, sí me gustaría que diera un sentido claro a su formulación del replanteamiento del statu quo. Es decir, yo no sé si alguien que ha apelado en los términos en que usted lo ha hecho, yo creo que muy categóricos, al sentido de la responsabilidad, a la política realista, a no hacer política-ficción, puede seguir manteniendo esos principios de actuación, cuando está proponiendo a la sociedad vasca, de algún modo, o a esta Comisión que tiene que ocuparse de estas cosas, pues, un planteamiento de ultima ratio, apelando a una autodeterminación que usted y yo sabemos que no es aplicable por el único que puede decir que la aplica, que son las 
Naciones Unidas, no es aplicable a ningún supuesto por el que pase la sociedad vasca, ni mucho menos la Comunidad Autónoma vasca. Y si usted puede abocar a estar sociedad -insisto- a esa ultima ratio después de decir que es imposible destejer el entramado político institucional vigente.

Es decir, yo no veo coherencia entre el modo en que usted se produjo como responsable político hace veinte años y el horizonte que nos marca en este momento. No veo la coherencia entre aquella responsabilidad histórica y esa apelación a la ultima ratio en los momentos históricos que vive la sociedad vasca. Y no le he oído tampoco ninguna valoración sobre la evolución político-social de esta sociedad.

Es decir, yo le recuerdo a usted elegido Lehendakari con dos tercios de vascos votando nacionalista, y hoy, que esa cifra está mucho más próxima a un 50 por ciento, no veo coherencia entre aquella apelación -insisto- al realismo político y esta apelación a una ultima ratio, que yo creo que es estrictamente un desideratum político-jurídico. Me gustaría conocer su opinión al respecto.

EI Sr. GARAIKOETXEA URRIZA:

A ver si me acuerdo de todo, señor Barreda. Intentaré responder a todas sus preguntas.

Bueno, en primer lugar, permítame que salga en defensa de mi compañero Knörr, porque hay un aforismo que yo creo que es especialmente caro a los periodistas, que dice que "las opiniones son libres, los hechos sagrados". No se trata aquí de sacralizar cosas, sino de traer un aforismo al que yo me he querido aferrar también refiriéndome a cosas concretas, a hechos en general, más que a opiniones subjetivas en la relación, larga relación que con la benevolencia de la Presidencia me he permitido hacer de mis experiencias al respecto.

De todas maneras, tiene usted razón: aceptando a efectos dialécticos que las interpretaciones a veces quedaban al aire por la necesidad de acudir a conceptos políticos indeterminados, lo que creo que está claro es que no hay aquí, ni en todo el arco político español, salvando algunos extremismos, nadie que no haya dicho que estaba dispuesto a la interpretación más amplia del Estatuto.

Ahí sí que podríamos decir aquello de "eso se lo dirás a todas", cuando la gente hace campañas electorales, cuando Felipe González, por el que tengo la mejor consideración y el mayor respeto, viene a Anoeta y dice "todo lo que cabe en el Estatuto"; cuando Fraga, que votó en contra, hoy dice que cabe lo que dicen ustedes que no cabe (presencia en Europa, etcétera, etcétera, etcétera).

De manera que, aun aceptando a efectos puramente dialécticos (no me coja usted las palabras literalmente) que fueran las cosas como usted dice, lo que está claro es que podíamos vivir tranquilos, porque no ha habido ni un presidente de Gobierno ni un partido político español que no haya dicho, desde el principio hasta el fin, que todo lo 
que cabe en el Estatuto es sagrado, hasta el punto de que ustedes son los principales abanderados del Estatuto en este momento. Y, claro, si se es abanderado, hay que ser abanderado con interpretaciones extensivas, no restrictivas.

Segundo. Hombre, me ha hecho usted una interpretación un poco -perdone- torticera de lo que yo he dicho del "café para todos". Lo que he dicho es que, a diferencia de Estatutos en los que existen limitaciones expresas, como incluso es el catalán, que no es un modelo de Estatuto el más descafeinado, en materias tan sensibles como las socio-laborales, en nuestro Estatuto no existen.

Y yo no he dicho con ello que suframos porque otros puedan alcanzar las cotas que quieran. ¡Estupendo! Lo malo es que sucede a la inversa, y ahí está lo que yo decía de interpretación un poco torticera. Y es que lo que se ha hecho es decir: "Como otros no tienen, ustedes, aunque tendrían que tener, no lo van a tener". Lo que equivale a decir: "Si ustedes piden esto, es que nos lo van a pedir todos", que es una cosa muy diferente.

Y yo quiero dejar muy claro, y lo he dejado siempre, creo, en mi época de mayor responsabilidad o cuando sea, que nos merece el máximo respeto el problema diferente y específico que tiene cada Comunidad. Tan respetable es el problema social que pueda haber en Extremadura y las soluciones específicas que pueda requerir Extremadura, con su postración histórica en materia económica, de paro, etcétera, o los problemas que pueda tener Andalucía, como los problemas que nos puedan angustiar aquí, de otra índole, a veces de carácter cultural, lingüístico, etcétera, además de los demás, claro. Pero yo no quiero decir con eso que queremos rebajar a nadie, sino que ha habido una argucia, que es rebajarnos a los demás apelando a los niveles de otros, que es exactamente lo contrario.

Hombre, el ejemplo de los puertos lo he puesto por poner un ejemplo muy gráfico, pero, hombre, no me lo saque usted como un rasgo de generosidad que no declare de interés general el puerto Elantxobe, o no sé qué cosa. Bilbao, Pasajes, a mí me parece que eran puertos que en este país existe capacidad para gestionarlos, desde luego, con tanto acierto, como mínimo, como los pueda gestionar el Gobierno central.

Y si alguien quiere discutir eso lo discutimos in aeternum, pero esa función tutelar que en las cosas importantes un Estado de tradición jacobina se ve obligado siempre a pedir, como si los demás fueran menores de edad, es la que incluso en lo que declara de interés general (que es poco, como dice usted), pues, yo creo que se lo podía ahorrar también, porque aquí hay gente cualificada y capacitada para que no necesite esa declaración para que las cosas funcionen como tienen que funcionar. Yo creo que en eso les podremos, en todo caso, dar lecciones, modestia aparte. No lo contrario.

La LOAPA. Mire usted, la LOAPA la tuvo que desautorizar el Tribunal Constitucional porque era impresentable, porque es que fue un escándalo aquello. Hasta la gente más ignorante y lega en materias jurídicas intuía que aquello era un despropósito, hasta el punto de que este país se movilizó (cosa que ahora ya no sucede tanto, por cierto) por una especie de entelequia como era la LOAPA para la mayoría de la gente. Y cuando 
el Vicepresidente de mi Gobierno, Mario Fernández, salió con Martín Villa a hacer un debate sobre la LOAPA, allí no sé si entendió, pero intuyó todo el mundo que aquello era tal despropósito que por vergüenza torera yo creo que el Tribunal Constitucional lo tuvo que descalificar. ¡Ojo, eh!, en una serie de artículos, bastante, fue una vergüenza para el legislador.

Pero lo grave no es eso, don Leopoldo. Lo grave es que el espíritu de la LOAPA ha sobrevolado desde entonces, y por la puerta falsa se le han hecho unos "by-pass" y todas las leyes básicas tienen pedazos de LOAPA como pianos de cola, y usted lo sabe perfectamente. Ésa es, por lo menos, mi humilde opinión. No voy a decir como aquel alcalde de un pueblo de aquí, de la Llanada Alavesa, que cuando discutía decía: "Eso será en su humilde opinión". (Risas.)

En veinte años, claro que hemos avanzado. Eso es lo que yo pretendía decir al señor Salaberria, que cuando un país tiene que resolver problemas hay que elegir el camino por el que uno sabe que puede ir resolviéndolos, y no darse de cabeza contra un muro haciendo que se pudran, y yo he citado antes una serie de cosas en las que no voy a volver a incidir.

¡Cómo no vamos a entender, a pesar de todas las opiniones que vemos que se vierten sobre el Concierto Económico, etcétera, que era mucho mejor eso que el expolio fiscal terrible que había antes, y que gracias a su aprobación, que fue muy laboriosa y requirió impulsos muy especiales, empezó a circular por este país una corriente de recursos financieros que permitieron que se acabara con una serie de situaciones verdaderamente angustiosas, y físicamente se pudieron ver esos efectos!

Pero, hombre, en esta vida las cosas no acaban ahí, señor Barreda. Nosotros entendemos que este Estatuto, que ha sido providencial para resolver con urgencia aquellas perentoriedades, tenía unas potencialidades que no se están aprovechando, y que lo que es más triste -eso es lo que he querido decir- es que con el tejido casi, casi imposible de destejer de leyes básicas, que ya constriñen cualquier posibilidad de desarrollo legislativo, por supuesto, e incluso de ejecución... Porque el problema no son las leyes básicas; el problema es que el propio Tribunal Constitucional ha dado carácter de básico a desarrollos reglamentarios y a decretos. Pues, claro, yo le digo mi opinión (ahí estoy, efectivamente, en lo opinable): yo creo que eso es irreversible.

Entonces, como un corolario de todo lo anterior, yo digo lo que he dicho antes, efectivamente, que yo creo que es mucho más fácil, como cuando uno dice que tiene que reconstruir un edificio piedra a piedra, y al final no tiene solución. Le podía poner un ejemplo, por cierto muy actual, pero no lo voy a hacer para no extenderme.

Es más difícil arreglar este asunto que hacer un replanteamiento. Segundo, yo creo que era más difícil lo que se hizo en el año 79 que lo que habría que hacer hoy. Tercero, yo creo que hay planteamientos que el grado de maduración democrática en la propia sociedad española, no ya sólo en la vasca, pues, puede asumir que en aquel entonces, sencillamente por cultura política, por inercias, por asuntos delica- 
dos en los que teníamos que tener también un sentido de la solidaridad con todos los pueblos del Estado, que se estaban jugando la implantación o no de un sistema democrático... No estábamos sólo con una mirada introspectiva hacia nuestros propios problemas; estábamos pensando en un problema que afectaba a mucha gente que merecía un rasgo de solidaridad a la hora de eso que tan peyorativamente se me ha interpretado, renunciaciones...

Siempre que se negocia hay renunciaciones, pero no en la acepción peyorativa del término, sino en la acepción positiva de saber negociar, entendiendo que todo el mundo tiene sus problemas cuando negocia. $Y$ en ese sentido yo creo que estamos en un momento histórico diferente.

Yo he dicho antes intencionadamente que a mí lo que me produce pena es que una solución cuyo alcance (el pacto estatutario) pudo tener una relevancia histórica, o pudo servir para un periodo histórico más relevante, se agotó de una manera desafortunada antes de tiempo, incluso para los que piensan diferente que nosotros.

Ni qué decir tiene que nosotros no hemos ocultado nunca, nunca, y, desde luego, el partido al que represento jamás, nuestra aspiración a otro marco de gobierno, a un principio y derecho que entendemos democrático, como es el derecho de autodeterminación, que por añadidura digo que, incluso haciendo abstracción de su utilización para ir a otras cotas de soberanía, desde el punto de vista de garantía para el débil en la negociación, como he dicho antes, cuando se producen estos contenciosos, es efectivamente el único recurso realista que ya queda, cuando uno ya no encuentra la imparcialidad que desea, a que aspira, en los órganos jurisdiccionales y cuando la fuerza de un Estado centrípeto demuestra que las soluciones a veces pactadas no se van cumpliendo.

Y yo no estoy de acuerdo en eso que dice usted. ¡No empecemos con la historia...! Podemos tener aquí un debate de 32 horas sobre la exclusiva reducción del derecho de autodeterminación a las situaciones coloniales, etcétera, etcétera, etcétera. Mire, yo traigo el testimonio de quien fue Director de Derechos Humanos de las Naciones Unidas, John Humphrey, que decía: "Pero esto ¿qué quiere decir?, ¿que los pueblos que no son colonias no son pueblos, cuando se ha formulado el derecho de autodeterminación de los pueblos?".

Otra cosa es que el oportunismo de los Estados, en toda época histórica, siempre ha procurado endosar las soluciones incómodas a los demás. Eso pasó después de la Primera Guerra Mundial, cuando Wilson proclamó a diestro y siniestro el derecho de autodeterminación pero luego sólo lo tenían que aplicar los vencidos en la guerra. Luego resulta que, como era una cuestión más simple, se le endosaba sólo a las colonias y a las situaciones coloniales el ejercicio de ese derecho. Pero la proclamación del mismo es una proclamación universal, y, como decía John Humphrey, los pueblos que no son colonias son pueblos. Y, desde luego, Euskadi es tan pueblo como cualquier colonia. No digo más, pero tanto sí. 
La PRESIDENTA:

Aurrera jarraituz, eta alderdien txanda amaitzeko, Euzko Abertzaleak Taldearen izenean, Egibar jaunak dau hitza.

EI Sr. EGIBAR ARTOLA:

Bai. Egun on, eta lehenengo eta behin Garaikoetxea jaunari eskerrak eman.

Besteak beste, garai hartan gazteago ginen denok -bai, batzuk besteak baino gazteago, baina- eta elkarrekin ere ibili ginen Estatutuaren inguruan nondik norakoak zabaltzen, eta nik eskertu nahi nizuke taldearen izenean besteak beste kokatu duzulako garaia; garaia, zer egoeratan zegoen herri hau, demokrazia ere bai Estatuari dagokionez eta zein izan zen nolabaiteko aurrebaldintza politikoa, nagusiena, eta horren inguruan nola txertatu nahi izan zen herri baten nahia, gizarte baten nahia, autogobernu-nahia, nahiz eta etorkizunak edo geroak erakutsi duen lege horrek zituen ezaugarrietan nagusienetakoa, paktuaren zentzua, alegia -eta nik uste dut oso ondo esplikatua izan dela paktuaren zentzua, baita ere moralki dagokion atalean-, nola hori alde bateko interpretazioarekin zapuztu egin den eta, azken finean, paktu politiko gisa azaldu zen hura momentu honetan lege arrunt bat gisa ezagutzen den eta legedi-sare horretan ezinezkoa zaion irtetea.

Ni bat nator diagnostiko horrekin, eta, batik bat, zentzu historiko hori mantenduz etorkizunari begira iragana ezagutzea ezinbesteko baldintza gertatzen den bezala, pentsatzen dut agerraldiaz gain ikasgaia ere izan dela -batzuentzat, behintzat-; eta, hain zuzen ere, azken finean egiten duzun planteamendua, hau da, autogobernuaren inguruko replanteamendu bat edo berrikuste bat, hori da batzorde honen egiteko bat. Eta etorkizunari begira garbi dago paktu politiko berri baten bila baldin bagoaz, bermeei dagokien garaian edo atalean, garantietan alegia, zutabe eta helduleku sendoagoak beharko dituela, ze, bestela, Estatutuarekin gertatu den bezala, gauza berdina gerta daitekeelako.

Galdera bat neukan, baina erantzun dezu bigarrengo honetan; baina hala ere ausartuko naiz egitera. Hau da: Estatutuaren sorreran, protagonista izateaz gain, ardura politikoa -guztia ez bada ere, nagusiena- zuen esku egon zanez, eta zure kasuan nagusiki ere, aurreikusten al zenuten -oztopoak egongo zirela, noski- hogeita bi urteko perspektiban hain xuhur eta maltzur joka zezaketenik Estatu-ikuspegi batetik gobernuburu izan direnek, jakinda, besteak beste, Estatutuaren inguruan arazo politiko bat egon, bazegoela, oraindik zoritxarrez indarkeriazko arazo bat badugula eta zuek egin zenuten ekarpena Estatu mailan ere demokrazia sendotzeko ekarpen nagusia izan zela?, aurreikus zitekeen iruzur hori hogeita bi urte pasa eta gero tamaina honetakoa izango zela? 
EI Sr. GARAIKOETXEA URRIZA:

Ez. Inondik inora. Beharbada pixka bat naif izango nintzen, baina jadanik garai hartan..., irakur ditzakezu deklarazio batzuk, nik egindakoak justu-justu hurrengo egunean, Estatutua onartu ondoren, esanaz "Orain kezkatzen nauena da bere garapena”. Eta bagenekien gauza zaila izango zela, kontuan harturik zer zailtasun aurkitu genuen negoziaketetan eta zer konplikatuak ziren alde politiko juridiko batzuk.

Baina, adibidez, Ertzaintza antolatzen hasi ginenean, ni gogoratzen naiz esaten nuenaz eta pentsatzen nuen oso epe luzea aipatzen nuenean "Bueno, goazen poliki-poliki, beharrezkoa bada, sustituzio hori eginez, eta, bueno, hamar urte behar badugu hori egiteko, ba, hamar urte pazientzia pixka bat izango dugu", eta hori hemeroteketan irakur dezakezu. Orduan hamar urte iruditzen zitzaigun, bueno, oso epe luzea zela garapen hori egiteko; baina garapen ezberdin bat, noski. Eta nik ez nuen pentsatzen inondik inora horrelako egoera batean aurkituko ginela momentu honetan, egia esateko.

Sentitzen dut.

La PRESIDENTA:

Bueno, galderen txanda amaitu eta gero, irtenbentzio honekin amaitzen dugu Garaikoetxea jaunak, lehendakaria ohiak, izandako interbentzioa; benetan eskertzen deutsugu, oso aberasgarria izan dalako.

Eta gai-zerrendarekin aurrera jarraituz, hurrengo partehartzailea hasi baino lehen, nik uste dot bost minutuko etenaldia emango dogula danontzako, eta bost minutu pasatu ondoren jarraitzen dogu gai-zerrendarekin eta daukaguzan zereginekin.

Eskerrik asko.

Eran las once horas y quince minutos. 